\title{
Ensuring Human Rights for Persons with Intellectual
}

\section{Disabilities?}

\author{
Self-determination Policies and the Use of Force in the Case of
} Norway

\section{Kjersti Skarstad, PhD Candidate, Department of Political Science, University of Oslo ${ }^{1}$}

\section{Abstract}

Individuals' equal right to make their own decisions and to control their own lives is fundamental to realizing human rights. The UN Convention on the Rights of Persons with Disabilities confirms this axiom by obligating States Parties to ensure that all persons with disabilities, including those with intellectual disabilities (ID), have the right to selfdetermination. However, the means by which this right can become a reality is poorly understood, and as yet very little information exists about how this right is implemented in actual state practice. This article applies five core human rights principles by which to evaluate how well states protect the right to self-determination for persons with ID. It uses this set of principles to assess Norway's performance. The article finds that despite Norway's commitment to protect self-determination, denial of the right is widespread. Strikingly, the right to self-determination is consistently denied because of disability status, and does not involve a careful case-by-case balancing of human rights principles. Violations occur because self-determination is not treated as core to human rights realization, and because many persons with ID are presumed incompetent to make decisions. Given these results, the article provides advice on how to improve practice.

\footnotetext{
${ }^{1}$ Many thanks to the guardianship and to the health office at the county governor of Oslo and Akershus for facilitating my research stay. Many thanks to Målfrid Braut-Hegghammer, Scott Gates, Vilde Hernes, Solveig Hillesund, Andreas H. Hvidsten, Jon Hovi, Kjetil Mujezinović Larsen, Simen Sørbøe Solbakken, and Michael A. Stein for comments.
} 


\section{Introduction}

The Convention on the Rights of Persons with Disabilities (CRPD) was enacted by the United Nations in 2006 to ensure the human rights of all persons with disabilities, including persons with intellectual disabilities (ID). Article 12 of the CRPD recognizes that persons with disabilities have legal personhood, meaning they have the right to make their own decisions and control their own lives. However, although the CRPD reaffirms that the right to self-determination is fundamental to realizing all human rights, achieving this right in practice is challenging. For nearly two thousand years persons with ID have had guardians appointed by their respective states to manage their interests by making decisions on their behalf (Fiala-Butora 2015). Consequently, violations of the right to self-determination for persons with ID are rampant (Arstein-Kerslake 2014; Fiala-Butora 2015; MDAC 2013).

Several academic studies focus on the legal and theoretical aspects of Article 12 and on the controversy about whether the self-determination of persons with ID can be restricted in cases where it would not have been restricted for others (Arstein-Kerslake 2014; Dhanda 2007; FialaButora 2015; Minkowitz 2007). However, empirical studies on actual state practices remain scant (Devi et al. 2011; Kohn and Blumenthal 2014; NOU 2016:17 ; Olsen et al. 2016; Werner 2012). This article contributes to filling this research gap by analyzing whether the self-determination practices of a selected country (Norway) are in accordance with widely accepted principles in the human rights literature. It likewise adds to the developing knowledge regarding legal capacity by making recommendations on narrowing the gap between principles and practices.

First, section 2 briefly explains why the right to self-determination is so important to human rights, and how Article 12 necessitates a move from substitute decision-making systems (decision making on behalf of others) to supported decision-making systems (individually based assistance enabling self-governance). Section 3 operationalizes five well-established principles of human rights theory and law, including the CRPD, to evaluate how states protect the right to selfdetermination of persons with ID: Practices must be targeted to respect, protect, and fulfill selfdetermination (human rights aim); persons with ID must be included in decision-making processes affecting them (participation); restrictions on the right to self-determination cannot be determined by disability status (non-discrimination); restriction of self-determination must be proportional to the aim (proportionality); and decisions concerning the right to self-determination must be transparent and impartial (legal safeguards). To protect the right to self-determination, the 
considerations and evaluations underlying a country's self-determination practices should be in accordance with these principles.

Section 4 explains the selection of Norway and the data applied to conduct the analysis. As is common among the States Parties to the CRPD, Norway has not, despite the CRPD Committee's decree to do so, ruled out the use of substituted decision making entirely (CRPD Committee 2014; UN Treaty Collection 2016). Norway declared upon ratification of the CRPD that substitute decision making can be used as a last resort, subject to safeguards. However, Norway has clearly proclaimed its acknowledgment of the right to self-determination for persons with $\mathrm{ID},{ }^{2}$ adheres to the human rights principles invoked in this study to evaluate performance (Barne-Likestillings-oginkluderingsdepartementet 2012-13; Norwegian Ministry of Foreign Affairs 2014; The Norwegian Government 2015), and enacted a new guardianship law designed to comply with the CRPD (The Norwegian Government 2015).

To evaluate whether Norway's system for protecting the right to self-determination for persons with ID works, all guardianship decisions concerning adults with ID for one of Norway's 17 county governors (regional government agencies) ${ }^{3}$ in 2015,167 in total, were analyzed. In addition, each of the same county governor's 121 coercive care decisions for 2015 for one municipality was examined. These documents are not publicly available and were difficult to access. All data were treated confidentially. Hence, to increase the results' verifiability and to control for whether the selected county deviated from the national standard, the county-level data were triangulated with interviews and publicly available national sources, such as complaint cases to the national guardianship appeal body, court cases, and secondary literature. Findings from the selected county governor were consistent with those on a national level.

Section 5 presents the findings and shows a large discrepancy between the human rights principles and actual practices. Denial of self-determination is extensive. Strikingly, the right to self-determination is consistently denied because of disability status, and does not involve a careful case-by-case balancing of different human rights principles. The root of the problem is that the

\footnotetext{
${ }^{2}$ Norway defines ID in accordance with the World Health Organization's (WHO) international classification of diseases: IQ below 70, limited abilities to adapt to the demands of daily life, and appearance of those limitations in childhood (NOU 2016:17).

${ }^{3}$ The term "county governor" can refer both to a Norwegian government agency and to the person heading that agency. In this text "county governor" only refers to the agency.
} 
right to self-determination is not treated as core to human rights realization, and hinges on the antecedent question of whether those targeted by guardianship procedures are considered competent to make decisions.

Section 6 gives policy recommendations on how the Norwegian system-and other substitute decision-making systems - can be replaced by a supported decision-making system that recognizes and enables the right to self-determination for each individual. Specifically, in cases where the individual lacks the ability to express needs and wants, the interests, personality, and lived experiences of the individual should be used to infer what the decision would be. In contentious cases, the harm that the individual might inflict on him- or herself should be balanced against the harm of being denied the freedom to decide.

The article provides important insights on a topic that extends beyond the Norwegian case, and beyond persons with ID. Guardianship laws target many (e.g., elderly people with decreased cognitive capacities, psychiatric patients, and persons with substance-use disorders), and several countries have started to question and reform traditional guardianship systems (Chesterman 2013; Crane 2015; Keys 2009). The article is likely the first in the literature to analyze the right to selfdetermination for persons with ID by evaluating administrative case files through the CRPD's stated principles. By drawing on the research fields of international norms, law, and public administration, it also contributes to the inter-disciplinary study of human rights.

\section{The Right to Self-determination for Persons with ID}

Legal capacity is a universal human right protected, inter alia, by the Universal Declaration of Human Rights (UN General Assembly 1948) and the International Covenant on Civil and Political Rights (UN General Assembly 1966). Legal capacity is explicitly protected for persons with disabilities by the CRPD (UN General Assembly 2007). In practice, legal capacity means self-determination - having self-governance, that is, making your own decisions and controlling your own life-within the confines of the law.

Recognition of legal capacity is indispensable for having human rights in practice because it constitutes individuals as rights holders and as actors under the law (CRPD Committee 2014). The right to self-determination is therefore not only a human right in itself; it is also a core principle inherent in all human rights. Thus, all human rights, including the rights to health, liberty, marriage, political participation, and even the right to freedom from torture, will be significantly 
compromised, if not completely voided, if the right to self-determination is denied. Forcible sterilization and clinical experiments, institutionalization, and the denial of meaningful participation in society are all examples of actual practices that states have legitimized by claiming that persons with ID cannot make their own decisions (Fiala-Butora 2015).

In addition, the interdependency of human rights (Glendon 1997; Stein 2007; UN General Assembly 1993) entails that protection of an individual's right to self-determination also requires protection of the individual's other human rights. For example, the rights to participation (CRPD Articles 29 and 30) and inclusion in the community (CRPD Article 19) are important means by which a person's identity and personality, and hence her or his preferences and capacities for making independent decisions, are formed. Moreover, individuals' possibility of meaningfully making their own decisions and controlling their own lives also depend on protection of such rights as education, information, and physical integrity. Sufficient protection of the right to selfdetermination thus requires states to apply a holistic human rights perspective.

Article 12 of the CRPD states that "States Parties shall recognize that persons with disabilities enjoy legal capacity on an equal basis with others in all aspects of life" (UN General Assembly 2007: para.2). Law and policies shall uphold the right to self-determination for persons with ID, and states shall refrain from interfering with the enjoyment of the right. Additionally, appropriate measures shall be taken "to provide access by persons with disabilities to the support they may require in exercising their legal capacity" (UN General Assembly 2007: para.3). States shall thus enable the right to self-determination by ensuring that those who need it are supported in their decision making.

A supported decision-making system seeks to assist and enable the individual's selfgovernance through a holistic protection of human rights. Decision-making support can, for example, be given through assisting with communication, providing information in understandable formats, and including the individual in networks where she or he can draw on advice from trusted peers (CRPD Committee 2014). If a person cannot express preferences or govern her or his own finances, for example, someone has to enable this right by making decisions reflecting the individual's interests. Such decisions must be based on the presumed will and preferences of the individual (Flynn and Arstein-Kerslake 2014). In contrast, in substituted decision-making systems, someone else has the power to make decisions on behalf of persons with ID according to what the decision-maker finds most suitable. 
In addition to the EU, the CRPD currently has 171 States Parties. It is controversial whether Article 12 allows for restrictions on the self-determination of persons with ID in cases where it would not have been restricted for others. The CRPD Committee allows no such restrictions (CRPD Committee 2014). A more common interpretation, supported by most States Parties, is that certain or all situations necessitate substitute rather than supportive decision making (Fiala-Butora 2015; MDAC 2013). Thirteen States Parties have expressed explicit reservations or made interpretative declarations about Article 12, confirming their view that self-determination for persons with ID should be subject to specific limitations (UN Treaty Collection 2016). In addition, three States Parties have expressed general reservations. ${ }^{4}$ Several States Parties, including Norway, have also advocated that the use of forcible treatment and substitute decision making be, under certain conditions, in line with Article 14 of the CRPD on the liberty and security of the person (UN Treaty Collection 2016).

This article invokes a set of widely recognized human rights principles to evaluate state performance. On their face, these core principles do not refute that Article 12 may allow denial of self-determination for a person with ID in certain situations where it would not have been denied for others. However, the principles have important implications regarding what grounds can be used to justify limiting the right.

\section{Analytical Framework: Core Principles for Political Systems that Enforce Self-determination}

This section operationalizes five well-established principles of human rights theory and law, including the CRPD, to evaluate how states protect the right to self-determination of persons with ID. It thus connects the specific requirements of CRPD Article 12 to universal human rights principles. The five principles selected apply to all human rights generally, are commonly invoked in the human rights compliance literature (Alexy 2005; Steiner et al. 2008; United Nations Development Programme 2000; United Nations Population Fund 2005), and should cover the most relevant aspects for evaluating rights realization in the present study. ${ }^{5}$

\footnotetext{
${ }^{4}$ In total, 30 States Parties have expressed reservations or made declarations about the CRPD. That $50 \%$ of these relate to Article 12 illustrates how contentious the article is.

${ }^{5}$ Naturally, the lists of principles used to evaluate human rights realization vary somewhat in the compliance
} 
1) Human Rights Aim. States should ensure that all human rights are respected, protected, and fulfilled (Eide 1987; Shue 1996). States respect and protect the right to self-determination by ensuring that state authorities or third parties (such as guardians) do not overrule decisions and life choices of persons with ID. States fulfill the right to self-determination by ensuring that those who need it receive decision-making support (CRPD Committee 2014). Paragraphs 1-3 and 5 of CRPD Article 12 codify the obligation to ensure equal legal capacity in all aspects of life through the support the individual might require. Persons with ID shall choose whether they want support and who their supporter(s) should be (UN General Assembly 2007). Persons giving support must seek to enable the self-determination of the individual in question. In cases where it is difficult to know what the person wants, their next of kin or friends often have important knowledge about the personality and general interests and preferences of the individual, which can be used to establish what the individual's choice would be if he or she could express it. To ensure efficient human rights protection, human rights training of both the supporter and the individual with ID may be necessary.

2) Participation. That persons should be able to participate in decision-making processes that affect them is a central democratic principle (Elster 1998). CRPD Articles 3a, 4.3, and 12 require that persons with disabilities be actively involved in decision-making processes affecting them. CRPD Articles 4.1.h and 21 manifest the right to accessible information. Persons with ID should receive necessary and targeted information, and they should be heard and represented in all matters concerning them.

3) Proportionality. In specific cases, human rights principles may collide with each other and most human rights may be limited in pursuit of a legitimate aim (Alexy 2005; Steiner et al. 2008: 1230; Strand 2012). The principle of proportionality requires that such limitations (the means) be

\footnotetext{
literature depending on what it is that is being evaluated (Risse-Kappen and Sikkink 2013; Simmons 2009; United Nations Development Programme 2000; United Nations Population Fund 2005). For example, in contrast to qualitative in-depth studies like this study, quantitative studies usually use a larger set of indicators to evaluate performance. The concept of progressive realization, or progress, is often invoked to evaluate performance. This study, however, evaluates performance at one time point only, and the lack of previous studies makes comparison impossible. However, the present study can be a baseline for future analyses. The concept of accountability, also often invoked in the compliance literature, is not used as an independent principle in this study, but is touched upon under the discussions of "human rights aim" and "legal safeguards."
} 
proportionate to the aim (goal) pursued (Reid 2012: 67; Steiner et al. 2008: 1230). The right to selfdetermination does not mean that people should be able to decide whatever they want in every situation-all countries have laws limiting individuals' self-determination in certain cases (e.g. to avoid that individuals harm others) (Fiala-Butora 2015). As explained in section 2, in this study, the right to self-determination is understood more fundamentally as self-governance which is interdependent with all human rights. The lack of protection of other human rights (such as healthcare, participation in society, and education) compromises the enjoyment of the right to selfdetermination. In certain cases, individuals' freedom to control their own lives may be compromised, for example, by their inability to stop self-harm. While it is disputed whether force can ever be consistent with Article 12 (Flynn and Arstein-Kerslake 2014; McSherry and Waddington 2017; Minkowitz 2007; Richardson 2013), this study invokes the principle of proportionality to evaluate the basis on which potential restrictions of the right to selfdetermination occur.

If self-determination in a specific case is to be limited, a clear argumentation about why this is strictly necessary to protect the rights and interests of the individual is needed. Restrictions on self-determination should occur only after carefully balancing human rights principles. As selfdetermination is fundamental to human rights, restricting it in a specific case is a step that should not be taken lightly (Alexy 2005). Only the minimum amount of force or coercion necessary to achieve a legitimate aim should be applied, after all other relevant options have been tried.

4) Non-discrimination. Any policy that has a direct or indirect discriminatory effect on a group constitutes a violation of human rights (Byrnes 2002; Fredman 2005; Nowak 2002). Differential treatment is not discriminatory if it seeks to even out injustices and is targeted toward ensuring that a vulnerable group achieves equal rights in practice, for example through reasonable accommodation, of which supported decision making is an example. CRPD Articles 3 and 5 codify the principles of non-discrimination and reasonable accommodation and CRPD Article 12.3 states that persons with disabilities should "enjoy legal capacity on an equal basis with others in all aspects of life." Restricting self-determination, for instance through substitute decision making, is a targeted, discriminatory practice if it is done solely on the basis of group membership, such as disability, gender, or race (Stein 2007).

5) Legal safeguards. The protection of human rights necessitates solid legal procedures that are impartial and transparent (Peerenboom 2004; UN General Assembly 1948). Persons with 
ID are particularly vulnerable to forcible treatment and abuse, and stand in a de facto asymmetric power relation to the persons meant to help them. Depending on their needs, individuals may need help with making crucial and intimate life decisions, including where and how to live and how to spend their money. The importance of maintaining self-determination over such issues, and the huge potential for abuse, make legal safeguards that ensure a just, transparent, and impartial operation of the system all the more important. Such safeguards include having efficient, impartial complaint mechanisms to scrutinize decisions, as described in Article 12.4 of the CRPD.

To protect the right to self-determination, the considerations and evaluations underlying a country's self-determination practices must reflect the five principles above.

\section{The Case of Norway}

Norway has clearly proclaimed its acknowledgment of the right to self-determination for persons with ID. Together with equality and participation, self-determination is the overarching Norwegian policy goal concerning persons with ID: Their choices and wishes should be considered and respected as far as possible, and policies should facilitate their decision-making (St.meld.nr.45 2013). Norway also adheres to the human rights principles invoked in this study to evaluate performance (Barne-Likestillings-og-inkluderingsdepartementet 2012-13; Norwegian Ministry of Foreign Affairs 2014; St.meld.nr.45 2013; The Norwegian Government 2015). In particular, the Norwegian Government clearly states that withdrawal of legal capacity solely on the basis of diagnosis or disability is contrary to the CRPD (Norwegian Ministry of Foreign Affairs 2014). To comply with its human rights obligations, Norway reformed its guardianship law before ratifying the CRPD (St.meld.nr.45 2013; The Norwegian Government 2015).

However, like other States Parties, Norway has not entirely ruled out the use of substituted decision making, nor has it committed itself to do so (CRPD Committee 2014; UN Treaty Collection 2016). Like Australia, Canada, France, and the Netherlands, Norway declared upon its ratification of the CRPD that substituted decision making can be used as a last resort by issuing the following interpretative declaration of Article 12 
Norway recognizes that persons with disabilities enjoy legal capacity on an equal basis with others in all aspects of life. Norway also recognizes its obligations to take appropriate measures to provide access by persons with disabilities to the support they may require in exercising their legal capacity. Furthermore, Norway declares its understanding that the Convention allows for the withdrawal of legal capacity or support in exercising legal capacity, and/or compulsory guardianship, in cases where such measures are necessary, as a last resort and subject to safeguards (UN Treaty Collection 2016).

Furthermore, in its communication to the CRPD Committee, the Norwegian Government states that the human rights principle of self-determination must be weighed against other human rights in situations where the assumption of legal capacity for persons with ID may compromise other rights, such as the right to life, the right to health, and the right to a fair trial (Norwegian Ministry of Foreign Affairs 2014).

The main purpose of this study is not to discuss whether Article 12 can (as the Norwegian government proclaims) be restricted in the more extreme cases (Fiala-Butora 2015; Flynn and Arstein-Kerslake 2014; McSherry and Waddington 2017; Minkowitz 2007; Richardson 2013), but to evaluate actual practices according to the five core human rights principles presented above. Norway's clear position on how Article 12 should be interpreted and Norway's attempt at reforming its guardianship system according to human rights principles make it a particularly interesting country to study in the present context. Does the Norwegian system work?

The stated purpose of the Norwegian guardianship law is to ensure that persons who need help and have a recognized diagnosis, such as ID, dementia, serious gambling mania, drug abuse, or seriously impaired health, have their interests taken care of by an appointed guardian (Vergemålsloven 2010). It is unclear whether a person's "interests" should be interpreted as the person's will and preferences. The law states that, generally, the person must agree to the guardianship, to its scope, and to the guardian. Moreover, the guardian cannot act contrary to the will of the person under guardianship. The Norwegian guardianship law does not apply terms like "supported decision-making" and "self-determination." Moreover, despite Norway's communication to the CRPD Committee on the importance of balancing self-determination with other human rights principles where this is strictly necessary to ensure other core human rights, Norway’s guardianship law does not clearly reflect this understanding (Vergemålsloven 2010). 
The Norwegian guardianship law acknowledges that the removal of legal capacity is a serious intervention; it should be reserved for the most extreme cases and must be established by a court (The Norwegian Government 2009: 7). However, the guardianship law also states that selfdetermination in a specific case does not have to be respected if the person does not understand the issue at hand (lacks competency), and that such competency is to be decided by civil servants (Vergemålsloven 2010). This clause creates a potential for broad denial of the right to selfdetermination. Whether this is the case needs to be established by an empirical analysis of administrative practices. However, already from the reading of the guardianship law it appears that Norway has challenges in terms of protecting the right to self-determination.

Of clear relevance to the protection of the right to self-determination is also Chapter 9 of the Norwegian healthcare law (hereinafter the law on coercive care). This law applies only to persons with ID and permits the use of force in cases where this is strictly necessary. The purpose of the law is to avoid that persons with ID harm themselves and others, and to prevent the use of force (Helse-og omsorgstjenesteloven 2016).

\subsection{Data}

Norway's 17 county governors are responsible for implementing the guardianship law and the law on coercive care. While the primary focus of the study is the practice of the guardianship law, coercive care cases are investigated to obtain further insights into how self-determination is protected. All 167 guardianship decisions concerning adults with ID for 2015 by the county governor of Oslo and Akershus were analyzed. ${ }^{6}$ In addition, each of the same county governor's

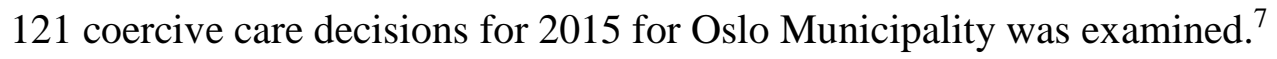

The county governor of Oslo and Akershus was selected because 1) it is by far the biggest county governor district, accounting for around a fifth of Norway's guardianships ${ }^{8}$ (Statens

\footnotetext{
${ }^{6}$ The guardianship data system is hard to navigate; therefore, cases had to be found manually with the help of the administrative appeal body, which could not guarantee that all cases for 2015 were identified.

7 This means that in Oslo, 121 persons with ID were under legal coercive care regulations in 2015. The national total is 1357 (NOU 2016 17: 129). These numbers include children. Of the 121 cases in Oslo, 11 were those of children.

${ }^{8}$ The number of persons with ID under guardianships is not known, but the total number of adults under guardianships was 36400 in 2016 (NOU 2016:17: 136). Around 75000 persons in Norway had an intellectual
} 
sivilrettsforvaltning 2016a); 2) it is near the average concerning the number of complaints to the administrative appeal body about guardianship cases, which indicates that it does not have a deviating practice (Statens sivilrettsforvaltning 2015e: 8); and 3) its leadership had a welcoming and cooperative attitude toward research. ${ }^{9}$

The new guardianship law and the CRPD entered into force on July 1, 2013. The year 2015 was selected because the changes envisioned by the new law should by then have been fully incorporated into practice.

Due to a challenging nine-month-long process of getting access to the documents, which are not publicly available, research was conducted at only one county governor. The data were treated confidentially and according to ethics guidelines for research in the social sciences (National Committees for Research Ethics in Norway 2006).

The law applies equally to all counties, and the underlying principles guiding decisions, which are the focus of this study, should be the same nationwide. Nevertheless, conducting research using material not publicly available, and originating from only one county governor, poses challenges regarding the verifiability of evidence used to draw interferences. To increase the verifiability of the results and to control for whether the selected county deviated from the national standard, the county-level data were triangulated with publicly available national sources, such as complaint cases to the national guardianship appeal body, court cases, and secondary literature. In addition, interviews were conducted with two senior advisors at the county governor, the director of the county governor's guardianship office, and with a major official of a human rights NGO for persons with ID. Findings from the selected county governor were consistent with findings on a national level, and hence (apart from the few instances where this is explicitly pointed out), the selected county governor complied with the intention and purpose of the Norwegian guardianship law. In total, the data should give a good picture of how Norway protects the right to selfdetermination for persons with ID.

disability in 2013; however, numbers from 2016 show that only 24000 persons were registered by the local municipalities (NOU 2016:17).

${ }^{9}$ Two other counties were also asked. One was also welcoming but the other did not want researchers to look at its decisions. 
All 167 guardianship cases of Oslo and Akershus in 2015 were coded quantitatively according to characteristics of the persons under guardianship (Figure 1), who the guardian was (Figure 2 ), and what the guardian's mandate was (Figure 3).

Already from these descriptive statistics, we can identify some problematic features of the guardianship system. Figure 1 shows that in only two (of the 167) cases the county governor suggested that the persons did not have legal capacity and thus referred the cases to a court. However, it is up to the civil servants at the county governors to establish whether a person has competency to make decisions (see section on the Case of Norway). Self-determination in a specific case does not have to be respected if the person does not understand the issue at hand (lacks competency). In almost 50\% of the cases the person was declared not competent. Hence, the county governor's possibility of overruling the self-determination of persons with ID affects many individuals. In $6 \%$ of the cases the person under guardian made a complaint about the guardian or the guardianship as such. According to the guardianship law, advisors should talk to the person with ID before establishing the guardianship (Vergemålsloven 2010). Nevertheless, the data show that advisors had in the establishment process spoken directly with the person with ID in only $13 \%$ of cases. However, in the interview, it was claimed that they had not registered all the conversations (Interview 2016b). 

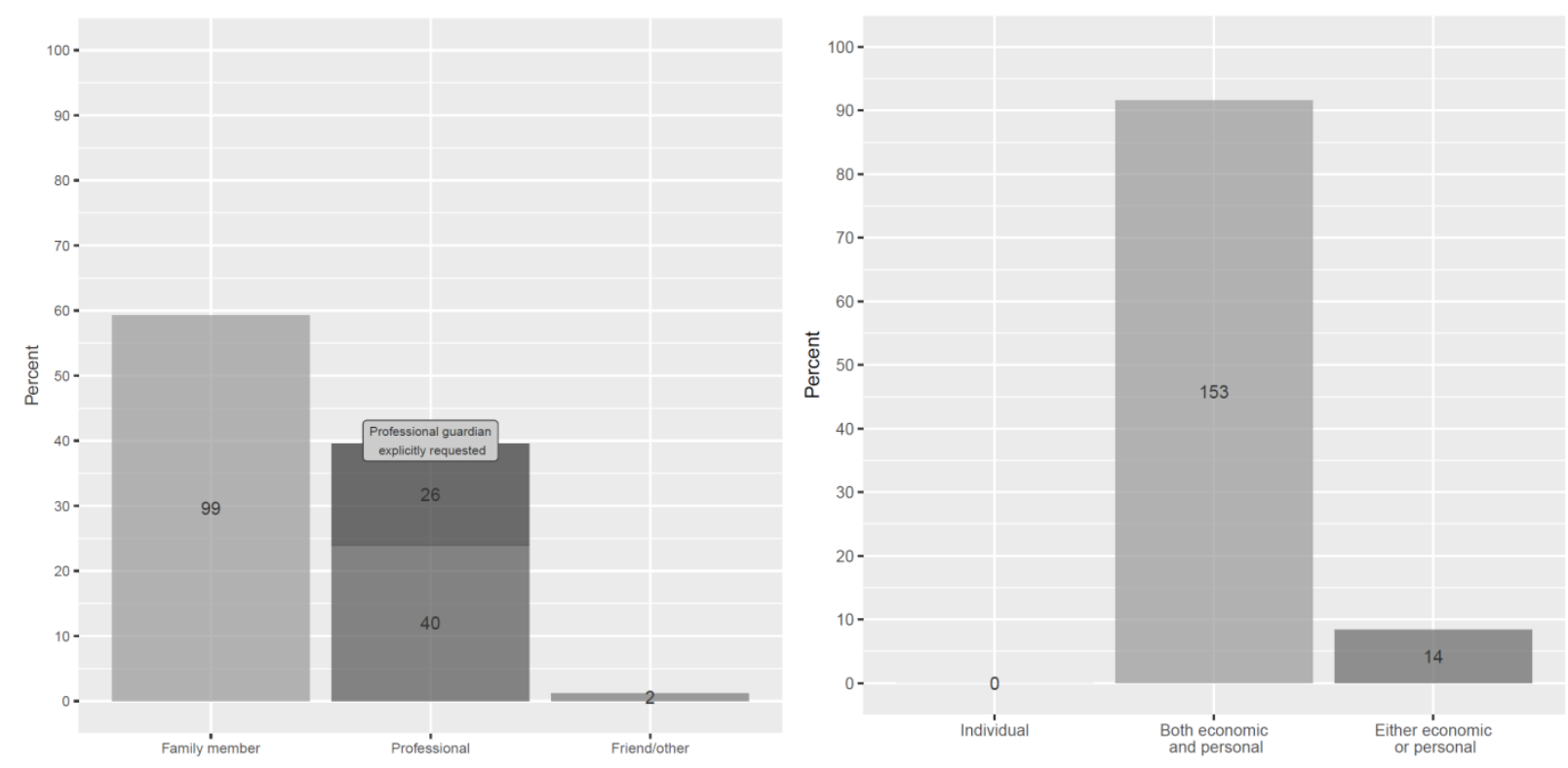

Figure 2 shows that in $40 \%$ of cases, the guardian is a professional, meaning that the guardian was recruited by the county governor. In around $40 \%$ of cases where a professional guardian was appointed, such a guardian was requested. In conflict with one of the main aims of the guardianship law (The Norwegian Government 2009), Figure 3 shows that no guardian had a mandate that specified what help the individual in question needed. Instead, guardian mandates are broad and generic. In almost $92 \%$ of cases, the guardian was to assist in both economic and personal matters, meaning that the guardian can write contracts, administer the economy, attend meetings, and in general make wide-ranging decisions on behalf of the person under guardianship.

\section{Findings}

Table 1 summarizes the findings on Norway's performance with respect to the principles set out in Section 3. Overall, there is a large discrepancy between what the human rights principles call for and actual practices. Sections 5.1 to 5.5 analyze in detail Norway's performance with respect to each principle. Here some context for understanding these findings is provided by way of briefly analyzing the main crosscutting issues affecting the whole system. 
Norway turns out to have a clear substitute decision-making system where the right to selfdetermination of persons with ID is consistently denied on the basis of their disability status. The root of the problem, affecting performance under each of the five human rights principles, is that the right to self-determination is not treated as core to human rights realization, and hinges on the antecedent question of whether those targeted by guardianship procedures are regarded as competent to make decisions. The guardianship system does not primarily aim to protect individuals' self-determination, or their participation in decision-making processes concerning them. Instead, it seeks to protect "the person's interests," which are defined by state-appointed guardians if the person is not considered competent to make decisions. This practice turns the Norwegian system upside-down: Denial of self-determination is not used as a last resort, but instead becomes more of a general rule.

Under the principle of proportionality, that the right to self-determination is not considered core to each individual's human rights realization is reflected by the fact that self-determination is denied without a careful case-by-case balancing of human rights principles. In guardianship cases, self-determination is denied for those not deemed competent, and in decisions concerning coercive care, the right to self-determination is not even mentioned. The Norwegian system emerges as discriminatory for several reasons: Only persons targeted by the guardianship law need to qualify for human rights others automatically enjoy; persons with more severe ID are often almost automatically deemed not competent (and hence denied the right to self-determination). Yet, all persons with ID can easily be found incompetent through an administrative process that does not apply strict legal safeguards. A lack of understanding of self-determination as core to human rights realization may also explain why guardians who criticize authorities and work actively for the rights of individuals with ID can easily be replaced.

The problem is not that persons with ID who have decision-making difficulties are identified, but rather that Norwegian authorities do not ensure that these persons receive sufficient decision-making support to enable their right to self-determination. Equally, the goal of taking care of persons who can harm themselves by making decisions is commendable: The problem is that evaluations of whether denial of self-determination is necessary are not informed by human rights principles, and that such evaluations are not conducted on a case-by-case basis. In the following, the findings under each principle will be explained in more detail. 
Table 1. Evaluation of Norway's system for self-determination. Results

\begin{tabular}{|c|c|c|}
\hline $\begin{array}{l}\text { Human rights } \\
\text { principles }\end{array}$ & Protected & Explanation \\
\hline $\begin{array}{l}\text { AIM } \\
\text { Respecting, protecting, } \\
\text { and fulfilling the right } \\
\text { to self-determination }\end{array}$ & No & $\begin{array}{l}\text { The guardianship law's protection of a "person's interests" is not } \\
\text { understood as prescribing the person's right to self-determination. } \\
\text { Denial of self-determination is not exceptional, but affects many and is } \\
\text { comprehensive for those who are affected. } \\
\text { Lack of adequate decision-making support. }\end{array}$ \\
\hline $\begin{array}{l}\text { PARTICIPATION } \\
\text { Including the } \\
\text { individual in decision- } \\
\text { making processes }\end{array}$ & Partially & $\begin{array}{l}\text { Persons with ID participate in the establishment of the guardianship, by } \\
\text { having to sign the papers, only if they are deemed competent. } \\
\text { Lack of accessible information. }\end{array}$ \\
\hline $\begin{array}{l}\text { PROPORTIONALITY } \\
\text { Self-determination } \\
\text { balanced against other } \\
\text { human rights } \\
\text { principles }\end{array}$ & No & Self-determination is denied on the basis of competency. \\
\hline $\begin{array}{l}\text { NON- } \\
\text { DISCRIMINATION } \\
\text { Contributing to } \\
\text { equality }\end{array}$ & Partially & $\begin{array}{l}\text { Persons with ID who need support in decision making receive a guardian } \\
\text { to help them, but the guardian is required to respect the self- } \\
\text { determination only of those deemed competent. } \\
\text { Persons with ID are in effect required to qualify for human rights that the } \\
\text { rest of the population automatically has. Persons with more severe ID do } \\
\text { not have the right to self-determination in practice. }\end{array}$ \\
\hline $\begin{array}{l}\text { LEGAL } \\
\text { SAFEGUARDS } \\
\text { Predictable, impartial, } \\
\text { and strictly regulated }\end{array}$ & No & $\begin{array}{l}\text { Evaluations of competency are inconsistent. } \\
\text { The system is arranged such that guardians who criticize authorities and } \\
\text { work actively for the rights of the individual with ID can easily be } \\
\text { replaced. }\end{array}$ \\
\hline
\end{tabular}




\subsection{Human Rights Aim: A System Designed to Support Self-determination?}

On its face, the revised guardianship law seeks to protect a person's "interests" (Section 4). From a human rights perspective, this goal is commendable, yet in practice, analysis of case files reveals that protecting a person's "interests" is not understood as acceding to an individual's own wishes and preferences, although at times they might coincide with those desires. An interview with the director and one of the senior advisors at the guardianship office of Oslo and Akershus (Interview 2016b) and a forthcoming book on the topic (Sande 2017) confirm that protecting selfdetermination is not the central aim of the guardianship system. Instead, as noted (Section 4), the revised guardianship law permits substitute decision making if the person is not considered competent to make decisions. In practice, this permission affects Norway's duties to respect, protect, and fulfill the right to self-determination.

Concerning the duty to respect the right to self-determination, the state extensively interferes with the enjoyment of the right to self-determination for persons with ID: Such interference affects many persons and is comprehensive for those who are affected. In some 50\% of all cases arising in Oslo and Akershus in 2015, the individual was declared not competent to decide whether to be under guardianship. No further evaluation of competency occurred concerning the extent and content of their guardianship, or who the guardian should be. Lack of competency on one issue was extended to entail lack of competency on other issues, leading to a general denial of self-determination. This practice was confirmed by interviews (Interview 2016b; Sande 2017). However, if no one protested or there were no other important considerations at stake, the county governor followed the wishes of the individual (if they were explicitly stated) regardless of the person's status as competent. To have self-determination, however, necessarily entails that you have the possibility to make decisions that others may disapprove of.

The county governor uses medical certificates in making competency decisions. Only one medical certificate from the 2015 guardianship cases in Oslo and Akershus separately evaluates the individual's different types of competency with a clear reference to what the individual might want. In that single case, the doctor writes, "I have talked to $\mathrm{X}$ and although it is unlikely that he understands what guardianship is he has faith in his mom's abilities to help him." This certificate is a good example of how one can work to ensure that the will of persons with ID is respected and enabled although they might have limited capacities for understanding the guardianship system. Some other certificates state that the suggested guardian and the person with ID have a close 
relationship — information that might indicate that the suggested guardian is qualified, or at least desired. Yet, whenever such information was lacking for persons deemed not competent, the county governor did not inquire about the individual's wishes, but complied with suggestions of guardians and with mandates of those applying for a guardianship on behalf of the individual with ID.

Concerning the duty to protect and fulfill self-determination, Norway has a system where those who may need decision-making support receive a guardian to help them. However, guardians can disregard the self-determination if the person under guardianship is deemed not competent. Guardians can, for example, apply for abortion, sterilization, and clinical experiments on behalf of "non-competent" persons with ID even though the person with ID opposes such treatment (NOU 2016:17: 122). Also, although county governors are required to scrutinize the guardians' administration of the economy of the person with ID, and to replace the guardian if there are reports of potential or actual abuse, few other mechanisms exist to ensure that guardians actually support the individual's self-determination, and little is known about how guardians conduct their work (NOU 2016:17).

Particularly noteworthy is that no national standards and requirements to train guardians exist (NOU 2016:17). Supporting someone's decision making is difficult if you do not know what this entails. The county governor of Oslo and Akershus, however, has created an obligatory course for professional guardians and gives information to local authorities (Interview 2016b). No course exists for family guardians, but they receive some guidance (Interview 2016b).

As a general rule, family guardians are not compensated (Statens sivilrettsforvaltning 2016b). For professional guardians the national salary covers around 17.5 to 25 hours of work a year (NOU 2016:17: 137, 39). This is, in most cases, insufficient time to get to know the person, and to give sufficient support. According to a human rights NGO, some professional guardians never even meet the person with ID (Interview 2017). If the guardian does not know the preferences, personality, and lived experiences of the person with ID, which is invariably the situation for the professional guardian when first being appointed, it is hard to see how the guardian can make decisions in accordance with the wishes of the person under guardianship when this person lacks the ability to give clear instructions. In such cases, the person's wishes may have to be inferred from broad knowledge about the person. However, guardianship laws and policies do 
not prescribe such an approach. In sum, a system ensuring that the right to self-determination for persons with ID is enabled through proper decision-making support is lacking.

The coercive care cases for Oslo in 2015 confirm that the right to self-determination for persons with ID is weakly protected. The law on coercive care requires services to be respectful of the individual's self-determination to the greatest extent possible (Helse-og omsorgstjenesteloven 2016). Yet, the county governor does not mention this requirement in any of the 121 coercive care decisions examined, indicating that the right to self-determination is not seen as a core principle of all human rights. During the interview the senior advisor said that they are concerned with individuals' self-determination, but that they are required to have short decisions, let the local authority documents be guiding, and follow the guidelines of the Norwegian Board of Health Supervision (Interview 2016a).

The absence of adequate protection of self-determination is not unique to Oslo and Akershus. Several public cases show that the national administrative guardianship appeal body does not consider the wishes of "non-competent" persons relevant to the outcome of the decision (Statens sivilrettsforvaltning 2015f, 2015d, 2015c, 2015b). ${ }^{10}$ A national inquiry into the human rights of persons with ID concludes that central institutions fail to protect the right to selfdetermination: Specifically, wishes and opinions of persons with ID are seldom considered in matters such as housing, health, education, and political participation (NOU 2016:17).

Court judgments directly addressing the right to self-determination for persons with ID are absent. A single district court judgment from 2015 does, however, address whether a couple aiming to support the self-determination of a woman with ID had violated the Criminal Code by infringing on her rights through ruthless behavior (Sør-Østerdal Tingrett 2015). According to the facts of the case, the couple let the woman voluntarily live in their house while she was waiting to buy her own apartment. Contrary to her wishes, the local authority transferred her back to a local authority household. The court stated that the couple had psychologically abused a vulnerable person by making her believe she could decide where to live, and by bringing media attention to her case (Sør-Østerdal Tingrett 2015). ${ }^{11}$ The court did not punish the couple because, inter alia, it believed

\footnotetext{
${ }^{10}$ These cases seem mostly to be about other groups targeted by the guardianship law, but the result would unlikely have been any different for persons with ID. Unlike the cases cited above, case VMM-2015-67 (Statens sivilretttsforvaltning 2015f) illustrates that the person's preference can be considered relevant.

${ }^{11}$ This indicates that human rights defenders have a narrow scope of action in guardianship cases, a point also
} 
they during the court proceedings had come to understand that they should not act contrary to what the guardian and the county governor had decided. In the appeal case in 2016, they were found not guilty, as their actions were found not to fall under the scope of the Criminal Code (Sør-Østerdal Tingrett 2016). The actual decision (self-determination) of the person with ID to live at the couple's place was not considered relevant to the case's outcome.

One Supreme Court case addresses the issue of self-determination for a psychiatric patient; such patients are also covered by the guardianship law (Norges Høyesterett 2016). The court considered whether the woman, who had a limited understanding of managing personal economy, should, as advocated by the county governor of Møre and Romsdal, lose self-determination over money she had inherited. She had already lost self-determination over her regular income, and in practice she had not been able to use her inherited money without approval from her guardian, although she was considered competent. The court decided by a 3-2 majority to take away entirely her right to self-determination in financial matters and that, given Norway's interpretative declaration on Article 12, the CRPD did not apply. The court denied the woman self-determination because her diagnosis could affect how she would spend her money and because her assets might be depleted. The small majority does, however, illustrate that restrictions on self-determination of persons under guardianship are contested.

Nevertheless, the two court cases confirm the extensive denial of the right to selfdetermination for persons under guardianships. They also confirm that the guardianship law's protection of a person's "interests" is not understood as acceding to an individual's own wishes and preferences. In practice, this understanding turns upside-down Norway's goals of protecting the right to self-determination and of denying it only in exceptional cases.

\subsection{Participation: Inclusion in Decision-making Processes?}

Process-wise, persons with ID participate in the establishment of their own guardianship only when being required to sign administrative papers, and then only when deemed competent. Papers establishing the guardianship seldom refer directly to the wishes and preferences of a person not deemed competent. Nor is there accessible information about guardianship or selfdetermination targeted to and shared with persons with ID. No such national standards and requirements exist (Interview 2016b; NOU 2016:17: 139). Information accessible to families

addressed in section 5.5 . 
lacking Norwegian language competency or knowledge about the Norwegian bureaucratic system also seems to be lacking.

All correspondence regarding establishment of the guardianship is sent to the person with ID regardless of that person's perceived competence, implying that due process is a concern. However, direct communication with the person with ID by the advisors is limited (see Figure 1, Section 4.1). After the guardianship is established, all official letters (including information from election authorities, welfare services, and banks) are sent to the guardian and not to the person under guardianship, regardless of competency status (Interview 2016b). This practice is due to how the Norwegian population registration system works, and the county governor representatives interviewed said that they hope this system will change (Interview 2016b). Nevertheless, the inconsistency demonstrates the lack of a system that sufficiently enables and assists persons with ID to participate in decision-making processes of utmost importance for their lives.

In coercive care cases, the lack of influence persons with ID have, especially in decisions concerning who will assist and work with them in their everyday life, seemed to be a reoccurring cause for uncontrolled or even violent behavior, often countered by force. The county governor often wrote that the local authority should aim to reduce the number of persons working with the person under coercive care. In one case, the county governor praised the local authority for carefully selecting assistants likely to stay long term and to be a good match for the person, indicating that such a process is seen an ideal. And yet, such a process seldom occurs. And not even in this praised case was a meeting with the person with ID part of the selection process.

Local authorities preparing the coercive cases for the county governor must report on the person's attitude toward the coercive decision and on the person's reaction to the coercion. Judging from the 121 cases for Oslo, some local authorities seem to do a good job of being in dialogue with the person with ID (both in advance and while coercion is ongoing), and pay attention to the person's attitude. Others do not. Some persons with ID are indifferent or express satisfaction after a coercive decision is implemented (for example, the locking up of personal items); others resist. In cases where employees used physical force to hold the person with ID so the person could not move, it was often reported that the person became quiet and calm after the use of force. This reaction, however, is not very surprising given that the use of force continued 
until this reaction occurred. The county governor did not refer to the attitude of the person with ID in any of the decisions for Oslo in $2015 .^{12}$

\subsection{Proportionality: Are Interventions Proportional to the Aim?}

The perceived competency of the person with ID decides whether the person has selfdetermination. Hence, interventions regarding the right to self-determination are not the result of case-by-case evaluations of different human rights principles. It is illustrative that nowhere in the Supreme Court majority decision referred to in Section 5.1 is there discussion of why depriving the woman of self-determination would benefit the woman herself, or in other words, why it might be necessary to restrict her self-determination in the specific case to protect her human rights (Norges Høyesterett 2016).

The minority position, however, illustrates what an evaluation applying different human rights principles might look like. The minority acknowledged that the individual had limited decision-making competency, but emphasized that self-determination should be denied only if strictly necessary and only with regard to the person in question or to those the person might provide for. Furthermore, the minority stated that if the person finds pleasure in spending her inherited money, it should not be considered a depletion of her assets. Hence, the central concern was whether the decision making led to satisfaction or was meaningful to the person under guardianship, not whether she would make decisions that were seemingly unreasonable by some external standard. Additionally, the harm of denying someone the ability to make decisions was clearly recognized, and not devalued because the person in question had a disability. Such evaluations were not found in the Supreme Court majority decision nor in any of the 167 guardianship cases of Oslo and Akershus.

The coercive care cases also demonstrate that self-determination is not treated as a core principle that applies to all human rights. Unlike in guardianship cases, in coercive care cases evaluation of proportionality is a strict legal requirement, supervised by the county governor.

\footnotetext{
12 The senior advisor interviewed explained that unless there is anything contentious in the material they receive from the local authority, they do not repeat facts in their decisions. If a person's attitude is not paid much attention in either the local decision or the county governor decision, it is likely a result of the person's low cognitive level (Interview 2016b). However, a persons' cognitive level should not determine whether authorities are attentive to their attitudes and ways of accommodating their participation.
} 
However, the county governor in Oslo and Akershus considered proportionality in the context of whether it was possible to limit the use of force particularly through preventive action and whether local authorities had tried to use measures other than force to avoid considerable harm. The cases considered did not contain any evaluation of whether it is legitimate to deprive someone of their self-determination to protect their health.

One case in particular illustrates the harm of not considering the right to self-determination. A person repeatedly stated he did not like where he lived and wanted to move. He was supported by his next of kin, who complained about his living conditions. The local authority argued that he needed support in his daily life. The county governor then approved of a coercive decision to install alarms on doors and windows and to trail him when outside, as he might try to run away. If the county governor had had a stronger mandate to protect self-determination, advisors could have reinforced his right to decide where to live, and they could more easily have instructed the local authority to arrange for a living situation acceptable to him.

The danger of a system focusing one-sidedly on protecting, for example, individuals' health is that this concern can easily become a goal in itself at the expense of individuals' overall freedom. Lack of attention to self-determination can contribute to making individuals into passive

receivers rather than active agents. At worst, a narrow focus on health concerns might, despite good intentions, lead to authoritarian tendencies: The enjoyment of human rights entails making choices that have both psychological and physiological consequences, also for persons with ID.

\subsection{Non-discrimination: Does the System Contribute to Equality?}

For many persons with ID, having someone to help them make decisions and, if they cannot express any preference, make decisions on their behalf according to their presumed preferences, is vital to enabling their right to self-determination. If guardians do a good job, this aspect of the Norwegian guardianship system contributes to protect the human rights of a vulnerable group, and comports with the CRPD. However, the right to self-determination hinges on the antecedent question of whether those targeted by guardianship procedures are regarded as competent. Consequently, persons with ID (and other persons under guardianship) are required to assert and then qualify for human rights that the rest of the population enjoy automatically. Restricting the right to self-determination because of disability is discriminatory (Section 3).

Doctors issuing medical certificates are asked to consider competency independently of diagnosis, but they mostly refer to the diagnosis or specify the diagnosis as a further means of 
judging competence. In all 167 cases for 2015, the county governor simply agreed with the doctor. While most persons registered as having mild ID and around half with moderate ID were considered competent, the usual course for persons with severe ID was to find them not competent. Thus, in practice, persons with severe ID do not have the right to self-determination. Due to their diagnosis (low cognitive capacity), they are very likely found incompetent to make their own decisions, and ensuring the right to self-determination for those who have such decision-making difficulties is not required by the guardianship law (Section 5.1).

From a holistic human rights perspective (see Sections 2 and 3), it is commendable that Norwegian authorities emphasize the need to care for vulnerable individuals who may seriously harm themselves if they make their own decisions (Norwegian Ministry of Foreign Affairs 2014). However, evaluating a person's competency or assessing the person's disability is not the same as determining whether such persons will harm themselves in decision-making situations. This approach does not reflect a human rights way of thinking. Many people struggle with making "competent" decisions; however, no one should need to qualify for human rights. We have human rights by virtue of being human (Nickel 2007; Stein 2007). Hence, in so far as certain individuals struggle with decision making, authorities' central concern should be to ensure that those individuals are assisted in a way that makes their inherent human rights realizable — not to deny them their human rights.

The coercive care cases also demonstrate that persons with ID are not accorded the same human rights standards as the rest of the population. The decisions examined leave little doubt that the use of force can be necessary and unavoidable to protect the life or health of persons with IDor of others. ${ }^{13}$ Examples include individuals with serious self-harming problems or severe obsessive-compulsive disorders, for whom other relevant non-coercive options have failed. However, a handful of cases (see examples under Section 5.2, 5.3 and 5.5) illustrate a discriminatory system that deprives persons with ID of self-determination in ways that would never have been accepted for persons without such a diagnosis.

\footnotetext{
${ }^{13}$ See, however, Minkowitz (2007) for an example of an author who uses other evaluation criteria and thus would not share such an interpretation.
} 


\subsection{Legal safeguards: Are Decisions Impartial and Predictable?}

Two findings are particularly noteworthy in the context of legal safeguards: 1) The evaluations of competency are inconsistent, and 2) the system is arranged such that guardians who criticize authorities and work actively for the rights of individuals with ID can easily be replaced. These two findings will now be addressed in turn.

As the right to self-determination hinges on one's competency, being declared not competent has the same implications as does losing legal capacity: In either case, persons lose the possibility to make their own decisions. Norwegian laws and policies confirm that taking away a person's legal capacity is a serious limitation of a person's freedom and should therefore be established by a court applying strict legal safeguards (Section 4). Nevertheless, strict legal safeguards do not regulate decisions concerning competency. Evaluations of competence are nonstandardized and vary in length from one sentence to several pages in the 2015 case sample. In addition, the standards are fluid.

In one case, the doctor writes that the person with ID is competent, only to reverse her assessment when it becomes clear that the person with ID has changed her mind and no longer wants to be under guardianship. In a similar case, the person with ID is found competent, but complains and wants the guardianship removed after it is established. The county governor approves, but a new medical certificate stating that the person is not competent is then sent to the county governor, resulting in the person being placed under guardianship once again. In yet another case, a person declared not competent goes to another doctor to get rid of his guardianship. The new doctor declares him competent. The ease by which persons with ID are declared not competent, and the lack of decision-making support (Section 5.1) mean that the right to selfdetermination is, at best, only weakly protected for persons with ID.

Guardians are, in the vast majority of cases, appointed without any disputes. In 2015, 10 individuals under guardianship, of the 167 cases examined, complained to the county governor of Oslo and Akershus about either the guardian or the guardianship as such. They said they did not want to be under guardianship, that they were not consulted in important life decisions and hence had lost control over their lives, or they stated they did not like their guardian and wanted a replacement. The county governor sent the complaint to the guardian and asked for the guardian's views. If the complaints were about a specific guardian, and especially if the complaints continued, the county governor replaced the guardian. 
In two of the 167 cases in 2015, a family guardian was replaced by a professional guardian, not because the person under guardianship wanted a replacement or because the family guardian was believed to harm the person with ID, but rather because the family guardian had a dispute with local authorities. ${ }^{14}$ In both cases, the guardian accused local authorities of illegally applying physical force to the person with ID, and complained about the living conditions of the person with ID. In one of these cases, the files show that the county governor followed up by interviewing the person under guardianship; however, there is no indication that the person with ID was asked whether he wanted the family guardian to be replaced. The county governor interviewed the leader of the shared house and two of his employees before reaching a decision, but did not meet the family guardian. This is a questionable practice, as the leader of the shared household and his employees are (like the family guardian) parties to the case.

In this case, the county governor stated that, generally, a guardian cannot be replaced because of a dispute between the guardian and service providers; however, the cooperation was so bad that it might have affected the interests of the person under guardianship. The decision was upheld by the administrative appeal body, which stated that a neutral guardian can do a better job of protecting the individual's self-determination. The accusations concerning forced treatment were not addressed, demonstrating that the right to self-determination is not seen as intertwined with other human rights. In the interview, it was confirmed that in cases of conflict, changing to a professional guardian might be preferable because a dispute with local authorities often makes the person under guardianship insecure and stressed, and hence is not in the interest of the person (Interview 2016b).

This study's sample is too small to generalize; however, other sources indicate that the cases are far from unique. A NGO has documented similar cases elsewhere in Norway (Norsk Forbund for Utviklingshemmede 2015). Two other administrative appeal body cases from 2015 confirm that cooperating well with local authorities may be more important for guardians than having a good knowledge of the individual's situation and preferences and a strong wish to help the person in need of guardianship (Statens sivilrettsforvaltning $2015 \mathrm{~g}, 2015 \mathrm{~h}$ ). ${ }^{15}$

\footnotetext{
${ }^{14} \mathrm{~A}$ few more cases indicate similar challenges, but in these cases, it is unclear whether a conflict with local authorities was the primary reason for replacement.

${ }^{15}$ In both these cases, another argument for replacement was that the guardian was not easy to contact. This argument, however, is given weight only in the case where the family guardian is replaced by a professional and
} 
It is important that guardians be able to cooperate well with other major actors working to improve the living conditions of the person with ID. Hence, the problem is not that a guardian can be dismissed for lacking such skills, but rather that the reason why the cooperation is not going well in a specific case is not addressed, and that the guardian replaced is implicitly seen as responsible for cooperation problems. A guardian's main task should be to, through supported decision-making, protect the rights of the person with ID (Section 2). Yet, the findings indicate that, ironically, the guardianship system is arranged such that guardians who criticize authorities and work actively for the rights of the individual with ID can easily be replaced. This is a major concern affecting the rule of law for persons with ID. ${ }^{16}$

The county governor's decisions in cases concerning the planned use of force build on a large amount of information and are governed by strict regulations. In most cases, the county governor instructed the local authority to improve routines affecting how force is applied, but the use of force itself was seldom questioned. The county governor is also responsible for scrutinizing reports from local authorities on the ad hoc (unplanned) use of force. These reports are seldom scrutinized and commented on. In 2015 Oslo had 2325 reports on ad hoc uses of force applied to 208 persons (Fylkesmannen i Oslo og Akershus 2016). ${ }^{17}$ According to the senior advisor interviewed, this neglect is due to capacity problems; they wish they had more time to scrutinize such cases, but prioritize examining cases on the planned use of force and having inspections (Interview 2016a). ${ }^{18}$ The senior advisor interviewed agreed that it is questionable whether the use

not in the case where a family member wanted to replace the professional guardian.

${ }^{16}$ The county governor did not see the replacement of family guardians as a problem and claimed that family members would still have the right to influence decisions (Interview 2016a). This right is, however, limited to involvement in healthcare decisions and does not include information and involvement in decisions concerning welfare and care (Pasient- og brukerrettighetsloven 2001), which are decisions affecting the daily lives of persons with ID the most (Interview 2017).

17 I read only a small minority of these reports.

18 The county governor conducted 37 inspections in 2015. Information and training of local governors are also a central task (Fylkesmannen i Oslo og Akershus 2016). There are very few complaints about the use of planned force (less than a handful a year), and almost no complaints about the use of unapproved force (Interview $2016 \mathrm{~b}$ ). 
of force in all of the ad hoc cases fulfilled the healthcare law's requirements on necessity and proportionality (Interview 2016a). ${ }^{19}$

\section{How to Improve Practice}

Although Norway has stated its commitment to protecting the right to self-determination for persons with ID and has proclaimed that it adheres to the five core human rights principles applied in this study, the Norwegian system is not working. In practice, Norway clearly has a substitute decision-making system, where the right to self-determination of persons with ID is consistently denied because of their perceived lack of decision-making competence. This section offers some policy recommendations on how Norway and other countries having substitute decision-making systems can make their practice more compliant with core human rights principles. Table 2, in the online appendix, summarizes these recommendations.

First, the right to self-determination should be treated as core to human rights realization. In practice, this right should be ensured by creating a national law and a system that primarily aim to respect, protect, and fulfill the right to self-determination of all persons with ID. For such a law and system to become a reality, Norway must clearly recognize that persons with ID can make their own decisions, and should provide sufficient decision-making support to those who need it. For example, in cases where the individual does not understand the issue or cannot express preferences - or needs and wants - the individual's interests, personality, and lived experiences should be used to infer what the individual's decision would be. In the words of Flynn and ArsteinKerslake (2014: 84) the decision-maker should act "in the way that she thinks the person would have wanted, if she were in a position to communicate her wishes." It is important that all guardians receive human rights training.

To ensure participation, those who make decisions directly affecting persons with ID should communicate with them, and they should carefully consider and make explicit references to those persons' wishes throughout the decision-making processes.

\footnotetext{
${ }^{19}$ In one case, a person explicitly said he wanted to be alone in his room. Employees ignored his wish and followed him into his room. When he responded with blows, employees held him by force, rather than simply leaving the room and accepting his wish to be left alone. Employees explained the use of force by stating that he was depressed and therefore should not be alone.
} 
In cases where respecting the individual's decision is particularly likely to harm the individual, the harm of denying the individual freedom of action should be balanced against the harm of accepting this decision. This approach can ensure the principle of proportionality. The threshold for denying self-determination should be higher the more the individual genuinely wants to make and carry out the decision, and it should be recognized that what gives life meaning is different for everyone. One person might, for example, enjoy experimenting with self-inflicted physical pain. Another person might conduct the exact same acts, but only because of deep psychological pain. In the latter case, it is a moral imperative to help. ${ }^{20}$

One way of keeping the primacy of the right to self-determination while acknowledging its potential conflict with other human rights principles in specific cases, may be to limit selfdetermination in such cases only if this will lead to more freedom in other areas of the individual's life. Hence, unless denying self-determination is necessary to protect the human rights of other individuals, the arguments for denying self-determination in a specific case should be about how it promotes the individual's subjective interests and lead to greater self-governance for the individual in total or in the longer run. To exemplify, consider a person with ID who finds great joy and takes great pride in her job. However, because she has become addicted to watching TV all night — an activity she expresses she does not really enjoy — she gets up too late to arrive at work on time. She is unable to break this habit by herself and does not understand that because of her behavior she might lose her job. In this case, denying self-determination in one area may be necessary to enable self-determination in other areas. However, further research on the strengths and weaknesses of such a proposition, and its compatibility with the CRPD, are needed.

To ensure non-discrimination, the right to self-determination should not depend on the person's competency. A fair and consistent system accurately establishing persons' decisionmaking competency - however one may define that in a manner that can apply in all cases — will be especially difficult to make (Fiala-Butora 2015). Moreover, to be non-discriminatory, competency tests should apply to everyone. But even then, they would contradict the core premise of human rights as rights one does not have to qualify for, but simply has by virtue of being human. Importantly, a competency-based system is not necessary to protect persons with ID from harmful decisions if the principle of proportionality (above) is implemented.

\footnotetext{
${ }^{20}$ See Section 3 for the basis on which such an intervention may be justified and the disagreement in the literature on the legality of the use of force also in extreme cases.
} 
To improve legal safeguards, practice should be consistent and transparent. The lack of court and public-appeal cases concerning persons with ID, and the difficulties for researchers to get access to public administrative decisions (Section 4.1) increase the risk of abuse and limit public discourse on state practices in the field. An independent entity should access, review, and supervise public administration cases concerning the right to self-determination, and decisions concerning the right to self-determination should be transparent. This entity should have the authority to challenge cases in court.

State authorities should enable guardians to scrutinize the living conditions and human rights situation of the person with ID. Guardians should not risk dismissal when a justifiable critique leads to cooperation problems with local authorities. Research on how guardians conduct their work in general is necessary to improve the system in the long term. Moreover, Norway should address the many cases of ad hoc use of force.

Finally, and affecting implementation of all principles above, the different parts of the public administration working on issues concerning persons with ID should cooperate to protect human rights holistically. The public administration should treat the right to self-determination as core to human rights realization, and they should explicitly evaluate ways of ensuring individuals' self-determination.

These recommendations suggest how the right to self-determination might be better protected, but do not provide a panacea. They raise some questions and concerns of their own. In particular, it will be important to find ways to ensure that those who make decisions on behalf of individuals who cannot express their own preferences do not abuse their position. This is, however, a stronger concern under systems that do not even provide human rights training of guardians and decision-makers. Also, while balancing different human rights principles in difficult cases will definitely be an improvement compared to denying self-determination on the basis of competency, the many stereotypes attached to persons with ID (Arstein-Kerslake 2014; Quinn 2011) may make it difficult to reach just decisions that do not treat individuals on the basis of their disability. The shift toward a system clearly informed by human rights principles should nevertheless lead to progress in this regard. 


\section{Conclusion}

Individuals' equal right to make decisions and to control their own lives is fundamental to realizing human rights. The CRPD makes it incontestable that also persons with ID have the right to self-determination. Yet, the right's implications for actual state practices are poorly understood, and studies on how states protect the self-determination of persons with ID are few.

This article conceptualizes the right to self-determination and invokes a set of widely recognized human rights principles to evaluate state performance. State practices should be targeted to respect, protect, and fulfill self-determination (human rights aim); persons with ID must be included in decision-making processes that affect them (participation); restrictions on the right to self-determination cannot be determined solely by disability status (non-discrimination); restriction of self-determination must be proportional to the aim (proportionality); and decisions concerning the right to self-determination must be transparent and impartial (legal safeguards).

This article applies this set of principles to analyze the performance of Norway — a State Party to the CRPD that has a firm position on how the right to self-determination for persons with ID should be protected. The analysis establishes that a large discrepancy exists between human rights principles and the actual practices of Norway. Despite commitments to protect selfdetermination and to adhere to the human rights principles referred to in thus study, the Norwegian system nevertheless extensively denies self-determination for persons with ID. Strikingly, the right to self-determination is consistently denied because of disability status, and such denials do not involve careful case-by-case balancing of different human rights principles. Violations occur because self-determination is not treated as core to human rights realization, and because many persons with ID are presumed incompetent to make decisions. Accordingly, protection of the right to self-determination is not the main priority of the guardianship system.

Given the results, the article offers some policy recommendations on how states can move from substitute decision-making systems, like the Norwegian one, to supported decisionmaking systems. Laws and policies should clearly recognize and enable the right to selfdetermination for each individual. In cases where the individual cannot express needs and wants, the interests, personality, and lived experiences of the individual should be used to infer what the decision would be. In contentious cases, the harm that individuals might cause themselves should be balanced against the harm of their being denied the freedom to make the choice. 
The article is unique in using administrative case files to analyze the right to selfdetermination for persons with ID, adds to the knowledge base regarding legal capacity, and provides important insights on a topic relevant to all groups targeted by guardianship laws. 


\section{References}

Alexy, Robert (2005), 'Balancing, constitutional review, and representation', International Journal of Constitutional Law, 3 (4), 572-81.

Arstein-Kerslake, Anna (2014), 'Restoring Voice to People: Realizing the Equal Recognition Before the Law of People with Cognitive Disabilities', (Dissertation, National University of Ireland).

Barne-Likestillings-og-inkluderingsdepartementet 'Meld.St. 45 (2012-2013) Frihet og likeverd - om mennesker med utviklingshemming [White paper 45. Freedom and equality - about persons with developmental disabilities]', < $<$ https://www.regieringen.no/no/dokumenter/meld-st-452012--2013/id731249/>, accessed 03.03.2014.

Byrnes, Andrew (2002), 'The convention on the elimination of all forms of discrimination against women', in Wolfgang Benedek, Esther M Kisaakye, and Gerd Oberleitner (eds.), Human Rights of Women: International Instruments and African Experiences (London: Zed Books Ltd), 119-72.

Chesterman, John (2013), 'The future of adult guardianship in federal Australia', Australian Social Work, 66 (1), 26-38.

Crane, Samantha Alexandra (2015), 'Is Guardianship Reform Enough-Next Steps in Policy Reforms to Promote Self-Determination among People with Disabilities', Journal of International Aging Law and Policy, 8 (2015), 177-210.

CRPD Committee (2014), 'General Comment No. 1', (http://www.ohchr.org/EN/HRBodies/CRPD/Pages/GC.aspx).

Devi, Nandini, Bickenbach, Jerome, and Stucki, Gerold (2011), 'Moving towards substituted or supported decision-making? Article 12 of the Convention on the Rights of Persons with Disabilities', ALTER European Journal of Disability Research / Revue Européenne de Recherche sur le Handicap, 5 (4), 249-64.

Dhanda, Amita (2007), 'Legal Capacity in the Disability Rights Convention: Stranglehold of the Past or Lodestar for the Future?", Syracuse Journal of International Law and Commerce, 34 (2007), 42962.

Eide, Asbjørn (1987), 'The Right to Adequate Food as a Human Right: Final Report submitted by Asbjørn Eide, Special Raporteur', (UN Doc. E/CN).

Elster, Jon (1998), Deliberative democracy (Cambridge: Cambridge University Press).

Fiala-Butora, János (2015), 'Reconstructing personhood: legal capacity of persons with disabilities', (Dissertation, Harvard Law School). 
Flynn, Eilionoir and Arstein-Kerslake, Anna (2014), 'Legislating personhood: Realising the right to support in exercising legal capacity', International Journal of Law in Context, 10 (01), 81-104.

Fredman, Sandra (2005), 'Providing equality: substantive equality and the positive duty to provide', South African Journal on Human Rights, 21 (2), 163-90.

Fylkesmannen i Oslo og Akershus (2016), 'Lov om kommunale helse- og omsorgstjenester kapittel 9. Rettsikkerhet ved bruk av tvang og makt overfor enkelte personer med psykisk utviklingshemming.', Helseavdelingen, Rapport 2015 (https://www.fylkesmannen.no/PageFiles/817396/Rapport\%20om\%20tvang\%20og\%20makt\%2 Oetter\%20KHOL\%20kap\%209,\%202015.pdf).

Glendon, Mary Ann (1997), 'Knowing the Universal Declaration of Human Rights', Notre Dame Law Review, 73 (5), 1153-90.

Helse-og omsorgstjenesteloven (2016), 'LOV-2011-06-24-30', (https://lovdata.no/dokument/NL/lov/2011-06-24-30).

Interview (2016a), 'Interview with a senior advisor, Øivind Pedersen, at the health section of the county governor of Oslo and Akershus.', December 14, Oslo.

--- (2016b), 'Interview with the director, Eldbjørg Sande, and a senior advisor, Marit Injar, of the guardianship section of the county governor of Oslo and Akershus', December 1, Oslo.

--- (2017), 'Interview with the assistant Secretary General, Hedvig Ekberg, of the Norwegian Association for Persons with Developmental Disabilities (NFU)', January 18, Oslo.

Keys, Mary (2009), 'Legal capacity law reform in Europe: an urgent challenge', Eur. YB Disability L., 1, 59.

Kohn, Nina A. and Blumenthal, Jeremy A. (2014), 'A critical assessment of supported decision-making for persons aging with intellectual disabilities', Disability and Health Journal, 7 (1, Supplement), 4043.

McSherry, Bernadette and Waddington, Lisa (2017), 'Treat with care: the right to informed consent for medical treatment of persons with mental impairments in Australia', Australian Journal of Human Rights, 1-21.

MDAC (2013), 'Legal Capacity in Europe. A Call to Action to Governments and to the EU', (Budapest: Mental Disability Advocacy Center (MDAC)).

Minkowitz, Tina (2007), 'The United Nations convention on the rights of persons with disabilities and the right to be free from nonconsensual psychiatric interventions', Syracuse Journal of International Law and Commerce, 34 (2), 405-28. 
National Committees for Research Ethics in Norway (2006), 'Guidelines for research ethics in the social sciences, law and the humanities', (https://www.etikkom.no/globalassets/documents/englishpublications/guidelines-for-research-ethics-in-the-social-sciences-law-and-the-humanities2006.pdf).

Nickel, James W. (2007), Making Sense of Human Rights (Second edn.; Malden: Blackwell Publishing). Norges Høyesterett (2016), 'HR-2016-2591-A', https://lovdata.no/dokument/HRSIV/avgjorelse/hr-20162591- $a ? q=H R-2016-2591-A$.

Norsk Forbund for Utviklingshemmede (2015), 'Samfunn for alle nr.5/2015', (http://www.nfunorge.org/contentassets/6a14974b5532449da1eaf33d0668c3fe/sfa5 2015.pdf ).

Norwegian Ministry of Foreign Affairs (2014), 'Draft General Comment No. 1 on Article 12 of the Convention on the Rights of Persons with Disabilities - submission by the Norwegian Government', (http://www.ohchr.org/EN/HRBodies/CRPD/Pages/DGCArticles12And9.aspx).

NOU 2016:17 'På lik linje. Åtte løft for å realisere grunnleggende rettigheter for personer med utviklingshemming. [On equal terms: Eight measures for realizing the basic rights of persons with intellectual disabilities]', Norges offentlige utredninger [Norwegian Public Inquiry], Oslo.

Nowak, Manfred (2002), 'The Prohibition of Gender-specific Discrimination under the International Covenant on Civil and Political Rights', in Wolfgang Benedek, Esther M Kisaakye, and Gerd Oberleitner (eds.), Human Rights of Women: International Instruments and African Experiences (London: Zed Books Ltd.), 105-18.

Olsen, Terje, et al. (2016), 'Kunnskapsstatus: Rettssikkerhet for personer med utviklingshemming [State of knowledge: rule of law for persons with intellectual disabilities]', NF rapport, 2016 (4).

Pasient- og brukerrettighetsloven (2001), 'LOV-2015-12-11-97', https://lovdata.no/dokument/NL/lov/1999-07-02-63?q=Pasient-ogbrukerrettighetsloven.

Peerenboom, Randall (2004), 'Human Rights and Rule of Law: What's the Relationship', Georgetown Journal of International Law, 36, 809-945.

Quinn, Gerard (2011), 'An Ideas Paper:'Rethinking Personhood: New Directions in Legal Capacity Law and Policy'or 'How to Put the 'Shift' Back into Paradigm Shift', University of British Colombia, Vancouver Canada, paper presentation, September.

Reid, Karen (2012), A practitioner's guide to the European Convention on Human Rights (4th edn.; London: Sweet \& Maxwell). 
Richardson, Genevra (2013), 'Mental capacity in the shadow of suicide: What can the law do?', International Journal of Law in Context, 9 (1), 87-105.

Risse-Kappen, Thomas and Sikkink, Kathryn (2013), The persistent power of human rights: from commitment to compliance (Cambridge: Cambridge University Press).

Sande, Eldbjørg (2017), 'Vergemål for voksne [Guardianship for adults]', in Eldbjørg Sande, Trine Eli Linge, and Mona Choon Rasmussen (eds.), Vergemålsloven og utlendingsloven kapittel 11 A med kommentarer.

Shue, Henry (1996), Basic Rights. Subsistence, Affluence, and U.S Foreign Policy (Princeton: Princeton University Press).

Simmons, Beth A (2009), Mobilizing for human rights: international law in domestic politics (Cambridge: Cambridge University Press).

St.meld.nr.45 (2013), 'Frihet og Likeverd - Om mennesker med utviklingshemming ', https://www.regieringen.no/contentassets/41a94b47679f477086d3f537d401d50a/no/pdfs/stm $201220130045000 d d d p d f s . p d f$.

Statens sivilrettsforvaltning (2015a), 'VMM-2015-67', (Accessed through Lovdatapro, https://lovdata.no/pro).

--- (2015b), 'VMM-2015-20', (Accessed through Lovdatapro, https://lovdata.no/pro).

--- (2015c), 'VMM-2015-13', (Accessed through Lovdatapro, https://lovdata.no/pro).

--- (2015d), 'VMM-2015-11', (Accessed through Lovdatapro, https://lovdata.no/pro).

--- (2015e), 'Årsmelding for vergemålsområdet 2015', http://www.vergemål.no/Images/Endelig\%20\%c3\%a5rsmelding\%20for\%20vergem\%c3\%a5lsom r\%c3\%a5det\%202015.pdf?epslanguage=no.

--- (2015f), 'VMM-2015-4', (Accessed through Lovdatapro, https://lovdata.no/pro).

--- (2015g), 'VMM-2015-1', (Accessed through Lovdatapro, https://lovdata.no/pro).

--- (2015h), VMM-2015-28.

--- (2016a), 'Antall vergemål i Norge', Statistics recevied by request.

--- (2016), 'Godgjøring og utgiftsdekning', <http://www.vergemal.no/Verger/Godtgjoring-ogutgiftsdekning/>, accessed December 13.

Stein, Michael Ashley (2007), 'Disability human rights', California Law Review, 95 (1), 75-121.

Steiner, Henry J., Alston, Philip, and Goodman, Ryan (2008), International Human Rights in Context: Law, Politics, Morals: Text and Materials (Oxford: Oxford University Press). 
Strand, Vibeke Blaker (2012), Diskrimineringsvern og religionsutøvelse. Hvor langt rekker individvernet? (Oslo: Gyldendal).

Sør- $\varnothing$ sterdal Tingrett (2015), '15-147348ENE-SOST'.

--- (2016), '16-079211MED-SOST'.

The Norwegian Government (2009), 'Ot.prp. nr.110. Om lov av vergemål (vergemålsloven)', Tilrådning fra Justis- og Politidepartementet, (2008-2009).

--- 'UN Convention on the Rights of Persons with Disabilities - Norway's Initial Report', <https://www.regjeringen.no/contentassets/26633b70910a44049dc065af217cb201/crpdinitial-report-norway-english-01072015.pdf>, accessed 03.01.2016.

UN General Assembly (1948), 'Universal Declaration of Human Rights', G.A. res. $217 A$ (III) (U.N. Doc A/810 at $71(1948))$.

--- (1966), 'International Covenant on Civil and Political Rights', UN Treaty Series, vol. 999, p. 171.

--- (1993), 'Vienna Declaration and Programme of Action', World Conference on Human Rights 12 July 1993, UN Doc A/CONF.157/23 (Vienna).

--- (2007), 'Convention on the Rights of Persons with Disabilities', UN Doc. A/RES/61/106, http://www.ohchr.org/EN/HRBodies/CRPD/Pages/ConventionRightsPersonsWithDisabilities.asp $\underline{x}$.

UN Treaty Collection (2016), 'Status of the Convention on the Rights of Persons with Disabilities', https://treaties.un.org/Pages/ViewDetails.aspx?src=IND\&mtdsg no=IV$15 \&$ chapter $=4 \&$ clang $=$ en.

United Nations Development Programme (2000), 'Human Development Report 2000', http://hdr.undp.org/en/content/human-development-report-2000.

United Nations Population Fund (2005), 'Human Rights Principles', http://www.unfpa.org/resources/human-rights-principles. Vergemålsloven (2010), 'LOV-2010-03-26-9', (Accessed through Lovdatapro). Werner, Shirli (2012), 'Individuals with Intellectual Disabilities: A Review of the Literature on DecisionMaking since the Convention on the Rights of People with Disabilities (CRPD)', Public Health Reviews, 34 (2), 1-27. 


\section{APPENDIX}

Table 2. How to improve practice

\begin{tabular}{|c|c|}
\hline $\begin{array}{l}\text { Human rights } \\
\text { principles }\end{array}$ & Suggestions \\
\hline AIM & $\begin{array}{l}\text { Create a law and a system that primarily aim to protect the right to self- } \\
\text { determination. } \\
\text { In cases where the individual has difficulties communicating preferences, infer what } \\
\text { the individual's decision would be from the interests, personality, and lived } \\
\text { experiences of the individual. } \\
\text { Provide human rights training to all guardians. }\end{array}$ \\
\hline PARTICIPATION & $\begin{array}{l}\text { Communicate with the individual with ID. Make explicit references to the wishes of } \\
\text { the individual in all decision-making processes concerning the individual. }\end{array}$ \\
\hline PROPORTIONALITY & $\begin{array}{l}\text { In cases where individuals want to make potentially harmful decisions, balance the } \\
\text { harm of denial against the harm of acceptance. } \\
\text { Set the threshold for denying self-determination higher the more the individual } \\
\text { genuinely wants to act in a certain way. Denial of self-determination in one specific } \\
\text { case should enable self-determination in other areas of the person's life. }\end{array}$ \\
\hline $\begin{array}{l}\text { NON- } \\
\text { DISCRIMINATION }\end{array}$ & $\begin{array}{l}\text { Abolish the system where the right to self-determination is determined by } \\
\text { competency. }\end{array}$ \\
\hline $\begin{array}{l}\text { LEGAL } \\
\text { SAFEGUARDS }\end{array}$ & $\begin{array}{l}\text { Practices should become more transparent. An independent entity should review, and } \\
\text { supervise public administration cases concerning the right to self-determination. }\end{array}$ \\
\hline
\end{tabular}

